\title{
Body and Etiquette: Practicing Propriety by Wearing Jade and the Origin of Confucian Myth-ritual*
}

\author{
TANG Qi-cui \\ Shanghai Jiao Tong University, Shanghai, China
}

\author{
WU Yu-wei \\ The Chinese University of Hong Kong, Hong Kong, China
}

\begin{abstract}
Etiquette (禮 Li, or ceremonial rules) is essentially a narrative symbol laden on human body (體 Ti). The practice and belief in etiquette and body are observable points which cannot be ignored in genetics exploration of “etiquette”. This article makees an archaeological excavation on “Li” (禮), “Ti” (體), and the metaphorical meaning of such phrases as “ringing jade to show etiquette” (鸣玉以相), “practicing etiquette by wearing jade” (佩玉践形) and so on. It finds that body, etiquette, and jade is a trinity in the Confucian ritual practice of the body, and even in ancient religious rites. The relationship is shown as below: external body (physical appearance)—etiquette and jade (media) - internal virtue (sacred power or holy force). The paper thus reveals the power source of the birth of rites, and the source link between holy rites and the mundane morals, which provide a new explanation of the origin of the "etiquette".
\end{abstract}

Keywords: body (體 Ti), etiquette (禮 Li), practicing etiquette by wearing jade, bodily thinking, confucian myth and rites, the origin of etiquette

\section{Introduction}

As the most technical and instrumental part of the ethical code and regulation, etiquette (Li) was the practice of the metaphysical part in Confucianism. According to the classical speeches of Gaoyao (臬陶谟) in Book of History (《尚书》), rites originated from destiny, Fatality Order constituted the basic root of ritual system's legitimacy (天秩有礼, 自我五礼有庸哉! ) 1 . The practice of etiquette has to be relied on the subject, the embodiment, interpretation and adaptation of human, who gives meaning to it. Thus the nature of etiquette is the symbol relied on human body. The practice and belief in etiquette and body are both significant perspectives in discussion the origin of Li.

Generally speaking, all the research and works on the origin of etiquette laid more emphasis on Li than Ti and restricted with the body view in literary records. However, they lack the insight into the body practice of the

\footnotetext{
*Acknowledgements: This paper is supported by China National Social Science Foundation "A Study on the Relationship Between the Myth of Ritual Vessels in Rites of Zhou and the Construction of Chinese ritual discourse" (13CZW022). Here I'm grateful to $\mathrm{Wu}$ Yuwei for her help to translate the article first.

TANG Qi-cui, Ph.D., is an Associate Professor in School of Humanities at Shanghai Jiao Tong University. Her main research fields cover Literary Anthroplogy, Ritual and Myth, Jade Culture, and Cultural Identity.

WU Yu-wei, M.A. in anthrology at the Chinese University of Hong Kong. She is devoted to the jade culture research in recent

years.
${ }^{2} \mathrm{Gu}$ Jiegang, Liuqiyu, Commentary and interpreter on the Book of History, Peking: Zhonghua Book Company, 2005 , p. 400.
} 
archaeological relics, especially regarding the practice of "Yu Ti (玉體, the body compared to jade)" in Confucianism. For example, the style and position of the jade artifacts in M4 burial site from Niuheliang of Hongshan Culture deserves attentions: The body of the owner of burial were headed toward east and lied on his or her back with crossed legs while the jade hood was located under the head and the jade Long were put on the chest. ${ }^{2}$ This could be considered as the typical example of body practice. The echo between the archaeological relics and literary records constitute the thinking model of body metaphor. So what's the relation between the fact of body practice and origin of etiquette? Although the archaeological scholars recognize the close relation between the jade-centered concept and the origin of etiquette, they lacked the perspective from human body and were restricted with the archaeological material.

Based on the tradition of jade culture lasting for 8,000 years and the metaphor of body as well as the mutual relation between $\mathrm{Ti}$ and $\mathrm{Li}$, this article tries to provide a new possible explanation of the origin of etiquette.

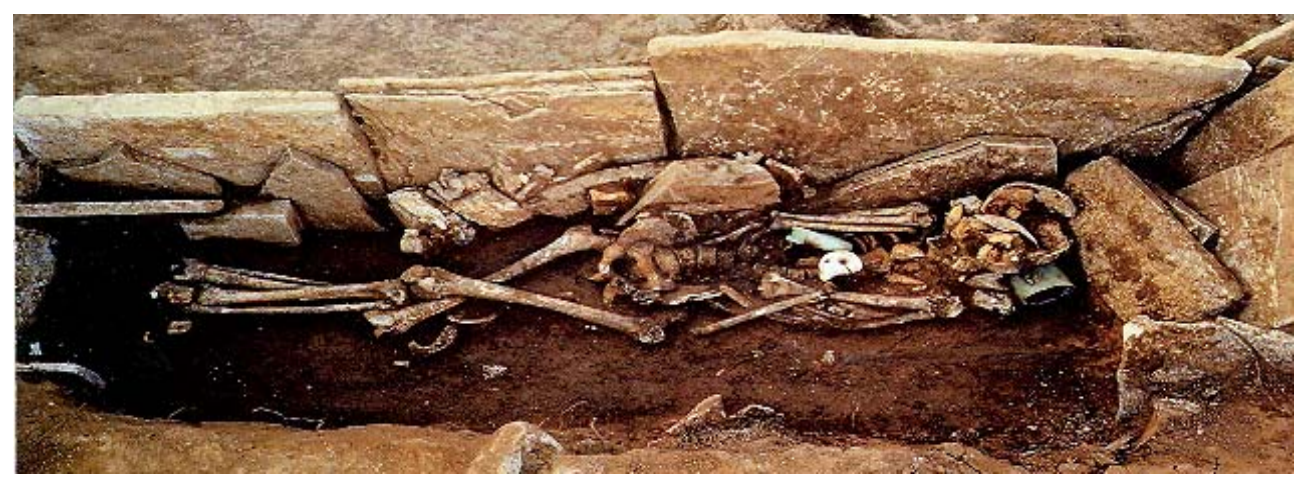

Figure 1. The image of Tomb 4 at Niuheliang site.

\section{Body and Etiquette: Body Thinking and Ritual Concept of Confucianism}

According to Utensils of Rites (礼器) in The Book of Rites (礼记 or A Collections of Treatises on the Rules of Propriety or Ceremonial Usages): Etiquette is just like body. Limbs missing will be known as not a human of completeness in gentleman's view, so it will be unprepared if ritual used improperly (礼也者, 犹体 也。体不备, 君子谓之不成人, 设之不当, 犹不备也). Here, the etiquette was compared to human body which stem from the body metaphor that human is an integral part of nature,gods, ancestor and parental body (神 是天之别体, 社稷山川是地之别体, 鬼是人之别体, ... 天地人之别体也). Thus, sacrifice to heaven, earth, mountains and rivers, and the gods of land and grain, and ancestors were mixed together in ancient China, and all means body completeness (已祭天地, 复祭山川社稷; 已事生人, 复祭宗庙, 谓之体备). ${ }^{3}$ The model of comparing human body as the subject of etiquette and the concept of "coming-of-age ceremony" all embody the close relation between etiquette and body. As said in Guanyi (冠义, or The Meaning of the Ceremony of Capping):

Generally speaking,that which makes man man is the meaning of his ceremonial usages. The first indications of that meaning appear in the correct arrangement of the bodily carriage, the harmonious adjustment of the countenance, and in

\footnotetext{
${ }^{2}$ Archaeological Insititution of Liaoning Province, Brief Excavation Report of Hongshan Goddess Temple and the Accumulate Stone Tomb at Niuheliang site, The Journal of Cultural Relic, 1986.8.

3 Ruan Yuan, Commentaries on Thirteen Classics, Peking: Zhonghua Book Company, 2003, pp. 1431-1435.
} 
the natural ordering of the speech... When the relation between ruler and subject is made correct, affection secured between father and son, and harmony shown between seniors and juniors, then the meaning of those usages is established. (凡人之所以为人者, 礼义也。礼义之始，在于正容体、齐颜色、顺辞令。 以正君臣、亲父子、和长幼。 $)^{4}$

Furthermore, the changes on appearance and the order of virtue mix etiquette and body together as well as become the thing and make human different from other creature. (凡人之所以贵于禽兽者, 以有礼也。故 《诗》曰: 人而无礼, 胡不遄死。 $)^{5}$ The etiquette guaranteed the operation of social life. Obeying this rule makes the people peaceful and the country prosperous while breaking the rule would irritate the god and the society would be in turmoil. This idea compared the individual body experience to the status of a country. The body become the symbol to enable the exchange between natural and social world.

And etiquette is the important media in this meaning exchange process: "The wise man who should attempt to regulate a state without etiquette (or ceremonial rules) would be like a blind man with no one to lead him.... If one have not the etiquette, he would not know how to dispose of his hands and feet, or how to apply his ears and eyes, and his advancing and retiring, his bowings and giving place would be without any definite rules" (治国而 无礼, 譬犹韾之无相与！...若无礼则手足无所错, 耳目无所加, 进退揖让无所制。 $)^{6}$ Thus, the etiquette explain itself with the help of the body: etiquette means bodily practice and self-cultivation, just as The Great Leaning(《大学》) says: From the son of heaven down to the multitudes of the people, all considered the cultivation of the person to be the root of everything besides (自天子以至于庶人, 壹是皆以修身为本) ${ }^{7}$. And the human body should become "grown-up" and sacred by means of practicing etiquette, the so-called eight outlines in The Great Learning such as investigation of things, extension of knowledge, retification of heart, sincerity of thought, self cultivation, family harmony, country management and world peace (格物、致知、正 心、诚意、修身、齐家、治国、平天下), are the ways to extend oneself (扩已) in order to make the individual body have a wider scope like the country and the world. Then it makes the individual body to contain the feature of nature or even makes everything self-evident and self-proved by means of empty oneself (虚已). It was used the imaginary thinking to enable body obtain the ability of reaching the unknown through memories and imagination, ${ }^{8}$ in order to reach the status of harmony with nature and become a part of the nature. Thus the body refer to a place exposing benevolent heart.

As Confucius says, see no evil, hear no evil, speek no evil, do no evil (非礼勿视, 非礼勿听, 非礼勿言, 非礼勿动), which were actually the interpretation of using etiquette to regulate and restrain the body aiming at cultivating and consecrating oneself and even becoming sage. According to Zhongyong (中庸, the Confucian ideal of moderation or the state of equilibrium and harmony), How complete is its greatness! It embraces the three hundred usages of ceremony, and the three thousand modes of demeanour. It waits for the right man, and then it is trodden.... Therefore the superior man honours the virtuous nature, and manifests an honest, generous, earnestness in the esteem and practice of all propriety. (优优大哉, 礼仪三百, 威仪三千, 待其人然后

\footnotetext{
${ }^{4}$ Ruan Yuan (2003), p.1679.

${ }^{5} \mathrm{Wu} \mathrm{ZeYu}$, Variorum of Yanzi's Spring and Autumn Annals, Peking: Zhonghua Book Company, 1982, p. 6.

${ }^{6}$ Ruan Yuan (2003), p. 1673.

7 Ruan Yuan (2003), p. 1673.

${ }^{8} \mathrm{Wu}$ Guangming, On Body Thinking of Tchouang-Tseu, In Yang Rubin ed. Qi Theory and Body Concept of Chinese Ancient Thought, Taibai: Ju Liu, 1993, pp. 398-399.
} 


\section{行。…故君子尊德性, 敦厚以崇礼。 $)^{9}$}

But only the most sincere people could go beyond the limitation of the physical body and become sacred. Thus the gentleman respects the etiquette from the bottom of their mind and practices moment by moment.Just as mencius says, The four cardinal virtues such as humanity, justice, propriety and wisdom have been rooting in gentleman's mind and shining in appearance. (君子所性, 仁义礼智根于心, 其生色也, 睟然见于面、盎于 背, 施于四体, 四体不言而喻). ${ }^{10}$ When the noble spirit (浩然之气) has been filling the world, they could overcome the limitation and integrate with the universe and transportation between the heaven and the earth.However,only those sacred people could achieve perfection though practice and cultivation (惟圣人然后 可以践形 $)^{11}$. But how do the sacred people know the way to communicating heaven? The specific answers could be found in Wanzhang of Mencius (《孟子·万章》) and The Five Elements on silk (帛书《五行》) from a tomb at Mawangdui (马王堆):

Saints Confucius epitomed the thoughts of morals and propriety.So Known as the token of Jinsheng Yuzhen or golden sound and jade vibration (孔子圣之时者也, 孔子之谓集大成。集大成也者, 金声而玉振之也). ${ }^{12}$

Golden sound and jade vibration means epitome of virtuousness. Golden sound, the metaphor of good which is representative of humanity, jade vibration, the metaphor of holy which is representative of natural law. Only saint can be able to make golden sound and jade vibration ....(金声而玉振之, 有德者也。金声, 善也; 玉振, 圣也。善, 人道也, 圣, 天道也。唯有德者然后能金声而玉振之) $)^{13}$

The saint has their best sight and an exquisite sense of hearing, which makes them easier know the oracles or informations from the universe. Thus, Confucius, virtue and jade constitude the archetype image of saint. ${ }^{14}$ Therefore, the beautiful jades are not only used as the media between deities and human in sacrificial rituals, but also used as an analogy of gentleman's virtue.

Thus it can be seen that etiquette relied on the body to practice and rooted in morality in order to construct a consensus worldly ideal on Being Human and then Being Saint. Furthermore, they even used the sacred objects as the media to go beyond the restricted body to reach the harmonious state of heaven and country. In another word, the practice of etiquette was basically constructed on the body thinking used the body as the figurative method to express ${ }^{15}$, to cultivate ones virtue (individually), organize the family well, administer a country (collectively) and communicate the heaven (spiritually). Thus, while we study the etiquette system, we should focus on those externality and extension of body which act as a important cultural constructor in the course of social change. Then, what's the externality and extension of ancient chinese body?

\section{Body and Jade: On the Perspective of Chinese Character Encoding}

The reason why saint could communicate with the heaven is that they have the sacred virtue the same as the

\footnotetext{
${ }^{9}$ Ruan Yuan (2003), p. 1633, trans. by James Legge, the Lī Kī, I-X, Part IV in The Sacred Books of China, Printed by Motilal Banarsidass, 1976 , p. 323.

${ }_{10}^{10}$ Ruan Yuan (2003), p. 2766.

11 Ruan Yuan (2003), p. 2770.

12 Ruan Yuan (2003), p. 2741.

13 Pang Pu, On Five Elenments of Silk Manuscripts, Jinan: Qi Lu Publishing House, 1980, pp. 34, 39-40.

14 Ye Shuxian, Investigate on Myth Archetype of Chinese Saint, The Journal of Wu hanUniversiry, 2010.3.

${ }^{15}$ Wu Guangming, On the Body Thinking of Tchouang-tseu, In Yang Rubin ed. Qi Theory and Body Concept in Ancient Chinese Thought, Taibei: Ju Liu Press, 1993, p. 395.
} 
god. And the external symbol of the inner virtue of saint and gentleman is the sacred objects with virtue - jade. As Confucius said in Pinyi or The Meaning of the interchange of Missions Between different Courts (《礼记·聘 义》), Anciently superior men found the likeness of all excellent qualities in jade, because jade possesses eleven kinds of qualities such as benevolence, intelligence, righteousness, propriety, music, loyalty, faith, heaven, earth, virtue, and the path of truth and duty. As is said in the ode, gentleman is graceful and gentle as a jade. This is why the superior man esteems it so highly. ${ }^{16}$ What Confucius said here affect profoundly and become the justified evidence of that gentleman was never without jade pendant excepting for some sufficient reason (君子无故玉不 去身), and that anciently superior man regarded the pieces of jade as emblematic of the virtues which he should cultivate (比德于玉). What's more, with the help of word of “formerly” (昔者), Confucius succeed in pushing its history into a long time ago, which justifies his says legitimacy.

Therefore, a man of honor have to wear jade, as to restrict himself, standardize his morality according to the quality of jade, discipline his act to the sound of jade beating. Just as the chapter Baofu (《保傅篇》) says, practicing etiquette at home and harmony with jade sound while walking.... heared the harmonious sounds of its bells when in his carriage, and those of his pendants jades when walking. The ornaments of jade composed of double Heng upper, double Huang under, and tooth-like piece, beads and other jade-stones pendants in the middle, colliding with each other. (居则习礼文, 行则鸣佩玉。…车以和鸾为节, 下车以佩玉为度. 上 有双衡, 下有双璜, 冲牙、玭珠以纳期间, 琚㻦以杂之。) ${ }^{17}$

Numous archaeological findings prove that a set of jade pendants on a girdle is exactly one unique kind of Chinese personal ornaments. For example, twenty-one sets of jade pendants on a girdle were found in different grades tombs of Guo State (虢国墓地, late Western Zhou dynasty) at Sanmenxia in Henan (河南三门峡), three sets of large-scale jade pendants of which were found matched with tripod lining system (列鼎制度) in the tomb of king (虢季M2001, 虢仲M2009) and princess (M2012). In the tomb of king, there are 7 tripods (鼎 Ding) and a set of large-scale jade pendants consisted of seven pieces of jade Huang and carnelian beads which was used to hang on the neck and pend to the belly. and in the tomb of princess, there are 5 tripods and a set of jade pendants consisted of five pieces of jade huang and carnelian beads. This suggests that a set of jade pendants on a girdle might be a symbol of status hierarchy.

\footnotetext{
${ }^{16}$ Ruan Yuan (2003), p. 1694.

Soft, smooth, and glossy, it appeared to them like benevolence; fine, compact, and strong, like intelligence; angular, but not sharp and cutting, like righteousness; hanging down in beads as if it would fall to the ground, like the humility of propriety; when struck, yielding a note, clear and prolonged, yet terminating abruptly, like music; its flaws not concealing its beauty, nor its beauty conceaning its flaws, like loyalty; with an internal radiance issusing from it on every side, like good faith; bright as a brilliant rainbow, like heaven; exquisite and mysterious, appearing in the hills and streams, like the earth; standing out conspicuous in the symbols of rank, like virtue; esteemed by all under the sky, like the path of truth and duty. trans by James Legge, p. 464.

17 Wang Pinzhen, Commentaries on the Book of Rite of Dai De, Peking: Zhonghua Book Company, 1983, p. 61.
} 


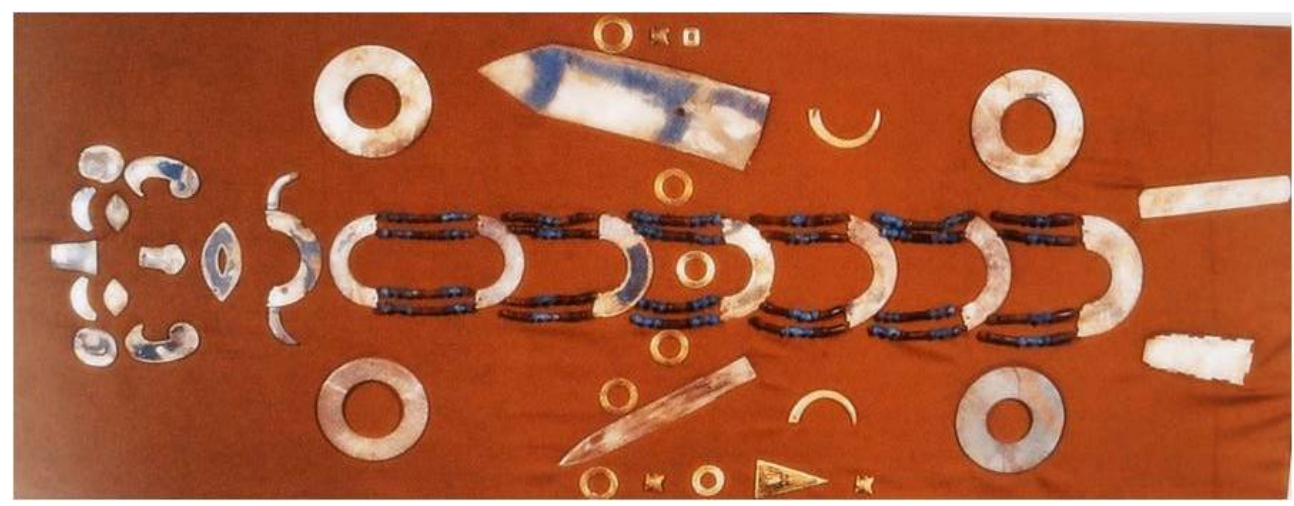

Figure 2. Seven set of wearing jade huang of West Zhou dynasty in the vassal King Guoji's tomb.

Although it's hard for us to clarify the exact time for the term, at least the history of the gentleman wearing jade could be traced back to quite far from now according to the archaeological relics. Based on the earliest fine jade ornaments like jade earrings and jade knife-ornaments found in Xinglongwa culture site (6211-5146 B.C.), this history could be traced back to 6000 B.C. The example of using the set of jade ornaments to indicate the social status of the burial's owner could be found in burial sites from Hongshan culture (3500 B.C.). And the set of tubes, beads, huang, Huan and small bi could be found in Liangzhu culture (3000-2000 B.C.). This tradition of wearing jade during lifetime and after death continued in Ming dynasty and Qing dynasty.

The purpose of wearing jade is not only to polish up the dress and appearance, to indicate the status and image of majestic, but also to improve ones inner virtue, to avoid the evil and prolong the lifetime. The common words and expression in ancient China classics such as Yuyin (玉音), Yubu (玉步), Gaiyugaixing (改玉改行) etc., all mean that gentleman use the sound of jades to discipline himself to act according to the etiquette. Regarding the form and meanings of it, the chapter of Yüzao (玉藻, The Jide-Bead Pendants of the Royal Cap) 《玉藻》 has more vivid expressions:

Anciently, gentleman did not fail to wear their jade pendants, the sound of jade with the pace must conform to the melody those on the right giving the notes Zhi (徵, which is equivalent to Sol) and Jue (角, equivalent to Mi), and those on the left Gong (宫, equivalent to Do) and Yu (羽, equivalent to La), and harmony with the music of Caiqi (《采齐》) when was walking quickly, and Sixia (《肆夏》) when was walking more quickly. When turning round, he made a complete circle, when turning in another direction, he did so at a right angle. When advancing,he inclined forward a little, he held himself up straight, and in all these movements, the piece of jade emitted their tinklings. So also the gentlman heard the harmonious sounds of its bells when in his carriage, and those of his pendants jade when walking. Thus, evil and depraved thoughts found no entrance into his mind. ${ }^{18}$

Here the jades or the sound of jades serve as the object to conduct Li and Yue together. That's the reason why it became treasure or important sacrificial vessels of state:

When one is holding a utensil belonging to his lord, though it may be light, he should seem unable to sustain it. In the case of a piece of silk, or a rank-symbol of jade such as Jade Gui Tablet (圭) or Jade Bi (璧disc) etc. used for ceremonial purposes, he should keep his left hand over it. He should not lift his feet in walking, but trail his heels like the wheels of a carriage. A minister should stand with his back curved in the manner of a sounding-stone (磬), and his girdle-pendants hanging down. Where his lord has his pendants hanging at his side, his should be hanging down in front;

${ }^{18}$ Ruan Yuan (2003), p. 1482. 
where his lord has them hanging in front,his should descend to the ground. (执主器, 操币、圭璧, 则尚左手。行不举 足，车轮曳踵。立则馨折垂佩。主佩倚则臣佩垂，主佩垂则臣佩委。 $)^{19}$

Thus the tradition of wearing jades could be compared to body discipline. Just as the saying goes, as a jade without chiseling will not become a useful object,a man without learning will not know the way. (玉不琢不成 器, 人不学不知义). The process of gentlman practicing etiquette and cultivating his moral may be likened to carving and polishing the jade (有匪君子, 如切如磋, 如环如磨). These sayings were all compared the process of carving jades to people's learning to persuade people keep regulating themselves and reach the perfect personality:graceful,modest sincere, gentle, holy and majesty as a beautiful jade.

Jade as the affiliations to human body and the authenticating objects for some ritual occasions, it becomes a part of the body under the regulation of individual spirit and body discipline in order to create the self domestication. However, if we put the perfect body appearance of Confucius and Zhao Jianzi into the circumstances where the society value that regulate ones body and virtue could help grown-up and being sacred, it would be easy to identify the ultimate pursuit of the outer etiquette of regulating oneself and the inner domestication from listening to the sound of jades: The harmony of outer beauty and inner peace was exactly the concrete expression of impressive and dignified manner (威仪迟迟). Thus, the tradition of polishing, dressing up, and training one's body so as to show the inner beauty had become the discipline of gentleman. Lao-tzu claimed that sage wore worn clothes while wore precious jade (被褐怀玉, it means that bebeath the coarse home-spun, one may discover talent and ability). Confucius compared himself to precious jade that expect a high bid. Mencius compared Confucius to the holy incarnation of jade. All of them revealed the etiquette value of jade. Zhao Jian Zi (赵简子) was set as the model for obeying regulation and etiquette in the Commentary on the Spring and Autumn Annals by Zuo Qiuming (《左传》) was the official with power and the founder of Zhao empire. His belief in golden sound and jade vibration (金声玉振) incarnated not only in the etiquette of serving the guests by jades, but also in the burial artifacts in Zhao Qing burial from Jin Sheng village (金胜村) in Taiyuan: 297 jade artifacts, and 32 musical instruments (19 bronze bells and 13 stone bells). The owner of the burial were found with a jade earring in the mouth and covered with jade Huang, Bi, Yuan, Zhang, Cong, Gui and tube etc. The crystal beads on the ankle and wrist were well made. ${ }^{20}$

According to this fact, the meaning of the chinese character Ti (體) could be re-defined. Viewed form the configuration of $\mathrm{Ti}$ (體) and $\mathrm{Li}$ (禮), there are recurring components li (豊) which happens to be the protoform of $\mathrm{Li}$ (禮) in inscriptions on bones or tortoise shells of the Shang Dynasty. In early twenty century, Wang Guowei suggested that the configuration of oracle li (整、装) composed of utensil Dou (豆) and Jue (珏, double piece of jade) demonstrating the meaning of serving jade with a vessel to the deity. The vessel to place jade for holy spirit is written as ${ }^{\circ}$. Thus the character “醴” means serve alcohol for the holy spirit, and “禮” means service for the holy spirit (像二玉在器 (即豆) 之形, 即盛玉以奉神人之器谓之豊, 推之而奉神人之酒谓之醴, 奉神人 之事通谓之禮). ${ }^{21}$ The subject of the etiquette ceremony is “軆”、“體” (Body). In a word, the character “豊” carried double meanings of sacrificial vessel at first: One is the sacrificial vessel (Jade or pottery), with the

\footnotetext{
${ }^{19}$ Ruan Yuan (2003), p. 1256.

${ }^{20}$ Zuo Zhenghua, The Tomb of Zhao Jianzi: The final Luxuxy of the Father of Jinyang City, The Journal of Chinese Culture Heritage, 2008.1.

21 Wang Guowei, Guan Tang Ji lin (or Selected Works of Wang Guowei), Peking: Zhonghua Book Company, 2006, p. 291.
} 
purpose of serving holy spirit and wish for blessing, the other is mankind. ${ }^{22}$

The archaeological evidences from the neolithic age suggested that the elaborate design of grave goods, especially kinds of beautiful carved jade objects which were the only buried on the tomb owner, signaled status and somewhat holiness. The kinds of carved jade objects should take the physical practice as the way to complete its mission, which means the jade had to have a physical media and a sacred pattern to communicate the deity. The jade artifacts from Hongshan culture and Liangzhu culture were mostly with deity, ancestor, sacred animal patterns to embellish the clothes. And some even was made into the shape of birds, fish, cicada, turtle, which were the animals considered as sacred and having the ability of longevity. Those could be the ornaments belonging to witch. $^{23}$ Thus I regard the jade as the symbol and ceremonial vessel of the one who could communicate the heaven.
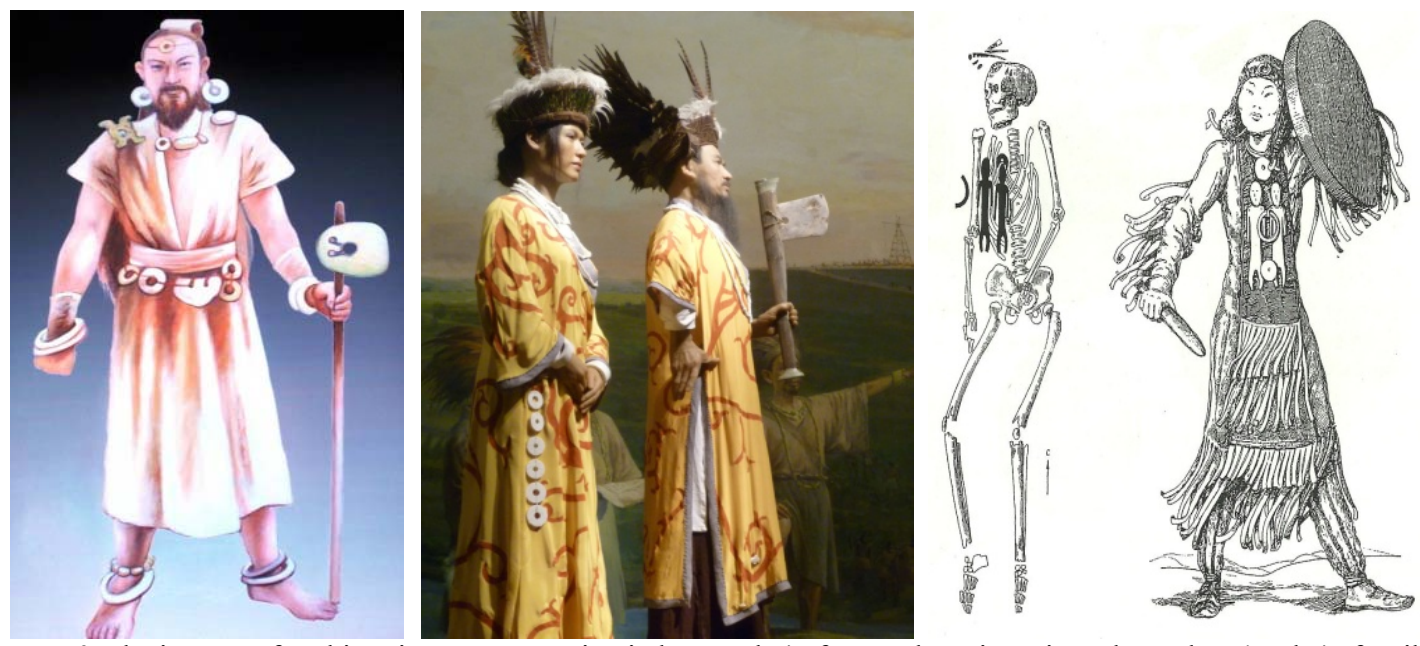

Figure 3. The images of prehistoric Prester wearing jade: Tomb 4 of Hongshan site, Liangzhu and Ust'-Uda4 of Baikal from left to right.

With regard to the duty of the officials of jade who provided jade pendants, beads and jade,jades kept in the mouth for his emperpr in Rites of Zhou (《周礼》), it was also obvious to identify the close relation between jade and body (apparel and accessories, funeral, sacrifices, oath of alliance, etc.) ${ }^{24}$. According to Hongfan in Shangshu (《尚书·洪范》 or The Great Plan in Book of History), only the king can eat jade (惟辟玉食) ${ }^{25}$, this suggested the tradition of eating jade was same important as the ruling and fortune of the empire.In chapter Guming (顾命) of Book of History, Emperor Cheng made a command before his death, it has the ritual effect of the power from the heaven. The ceremony of becoming the empire and demonstrating the jade artifacts justify the fact of taking charge of the whole world. As said in the preface of Book of History ( 《书序》), when Shang Tang defeated the troops of Xia, he confiscated all the treasure jades of emperor Xia Jie. Later, When king Wu of Zhou defeated the troops of Shang, he also confiscated all the treasure jades of Shang dynasty. These all reflect the image of the winner taking charge of the objects of the losers. In this situation, the jade became the symbol of the power of the heaven and the empire.

\footnotetext{
22 Tang Qicui, Li (禮, Etiquette), Ethnic Arts Quanterly, 2014. 3: 22-29, 35.

${ }^{23}$ Mou Yongkang, Rice, Silk and Jade: Some Questions on Origin of Chiese Civilization, The Journal of Archaeology, 1993.6.

${ }^{24}$ Sun Yirang, Commentary on Rites of Zhou, Peking: Zhonghua Book Company, 1987, pp. 452-461.

${ }^{25} \mathrm{Gu}$ Jiegang, Liuqiyu (2005), pp. 1172-1173.
} 
Based on the literary records and the body practice buried with carved jades in archaeological relics, the character Ti (體) was not only a word composed of image and pronunciation, and it might also indicate the interpretation and meanings of the character, which result from the long history of body practice and the code of the character from the long history. From the beginning of the whole universe and the practice of wearing jade, jade, body and etiquette have a inner relation with each other.

\section{Yuti (玉體): Body Metaphor and the Holy Origin of Etiquette}

Why the prehistorical Chinese people picked the jade as the holy and symbolized object? The answer was hidden in the relation between the metaphor and the myth of jade.

Zheng Xuan (郑玄) regarded that the jade article as sacrifice to gods and ancestors such as circular Bi (圆璧, disc), square Cong (方琮), Gui (珪), Zhang (璋), Hu (琥), Huang (璜), no matter the material, style, patterns and symbol all have the feature of the god in order to have witchcraft power. ${ }^{26}$ To the dead ones it represents the object to communicate the heaven and the ground in order to maintain the body. It might be the long-lasting character of jade and incarnate the nature of world. It becomes the best place or object for the deity to appear and even the essence of the world. In the myth of jade and body, jade is not only the holy place, burial or symbol of reproduction worshiping, but also the symbol of the shelter of the deity, the mind of people and the regeneration. Thus people would bury the jade with them when they are dead in order to guard the body and spirit.

In the society ruled by jade religion, the individual status was closely related to the relationship between individual and his ancestor or deity, or holy jade. It was clearly presented in the myth of insulation the earth from the heaven (绝天地通) and the prehistoric practice of jade burial. In Hongshan culture, every accumulate stone tomb only had one central tomb buried with well-made artifacts of certain functions like hooked cloud-shaped jade (勾云形器), hoop-shaped jade (筷形器), jade tortoise, jade dragon, jade phoenix, jade owl, fully indicating the power and position of an monopoly emperor. ${ }^{27}$ In the literary records, the power of communicating the heaven belong to Boyi (伯夷), XiaYu (禹), ZhouJi (稷), after Zhuanxu (颛顼) took over the way to the heaven ${ }^{28}$. And these three emperors had mysterious relation with etiquette and jade. Boyi as assistant of emperor Yao (帝 尧) was known as proficient in rites of communicatewith deities. It's said that Yu was born in Shiniu (石紐) mountain and live in Jishi (积石) mountain where all related to stone. It's important that he received the jade gui from heaven and to become the emperor because of his success in control the flood. The wild of Duguang where Hou Ji buried have everything, especially gold and jade. In a sense, these kings whose divine power from God were exactly through wearing jade,eating jade and born or lived in jade mountain etc. to cultivate themselves and then to obtain their ability of communication with deity. The holy emperor like Xuanyuan, Zhuanxu, Yao, Shun, Yu and Ji were all related to the jade mountains (玉山), such as the Mishan (峑山) belonged to Kunlun mountains was considered as the park for Yellow Emperor to plant and eat jade: there are many white jades in Mishan (峑 山), Dan River rises in Mishan and ends in Ji Marsh (稷泽). Therefore, there have plenty of white jades and Yugao (玉膏) in Ji Marsh provided to Yellow Emperor for eating and entertaining other supernatureal beings.

\footnotetext{
${ }^{26}$ Ruan Yuan (2003), p. 762.

27 Yang Hu, Liu Guoxiang, On jade culture of Xinglongwa, Deng Cong ed. Jade of East Asia, Hong Kong: The Chinese University of Hongkong Press,1998, p. 135.

${ }^{28}$ Gu Jiegang, Liuqiyu (2005), p. 1901.
} 
Moreover, Yellow Emperor brought the jade of Mishan mountain to Zhongshan mountain to germinate, and then provided to gods and ancestors as delicious food and to gentlemen as amulets (天地鬼神, 是食是饗; 君子服 之, 以御不祥). ${ }^{29}$ The jade could not only be eaten but also be planted, which indicate the jade had the power of life like a seed.

According to myth and legend said,the Kunlun mountain was the stair to the heaven and the center of the universe and the womb of the world. The Kunlun mountain becomes the metaphor of the body of world. This meaningful prototype of body metaphor was alive as the meaning of honorable, beautiful and kindness. Thus the jade has two metaphors in Confucian: seed and body. Therefore, the human body was the bridge to the world, the cause of the order and rules, the final pursuit of human to become the deity in the perspective of symbolized culture and society. This was decided by the conflict between the fate of body and human's eager to escape from the fate.

Almost all the myth of the origin of the world told the fact that human were born in the fairyland without illness or death but finally got kicked out because of greed and weakness. Thus the individual and the world were separated. The human body was separated from the holy body while he was still not satisfied with the fact of life-and-death circle. The human body was in fact the vessel of the mind and spirit. The pursuit of eternity becomes the final pursuit of human. And this was just the importance of all moral. As a matter of fact, they hope that they could get back to the ancestor's place, eat what their ancestor eat, do what their ancestor do, and get the power to live long by journary of dreams. In addition, they had the respectful ceremony to serve the supernatural beings in order to get protection and reach immortality. The sacrificial cow and goat, jade pendents, jade Gui and jade Bi were all used to serve the ancestor to get fortune and solve the danger.

People give sacrificial things with a will to get more, in another words they hope the things favored by the deity could exchange the safety, good luck and bliss from the deity. Thus the nature of ritual, etiquette or ceremony were actually the exchange of right and power in order to maintain the order of the society. The jades used in rituals and ceremony from eight thounsand years ago were exactly hierophony of energy exchange. This was the origin and the meaning of the myth and the holy ritual.

So Xun Zi suggested that there nothing more lightness than jewelry and jade among the things, and there nothing more lightness than etiquette for human being (在物者莫明于珠玉, 在人者莫明于礼仪) ${ }^{30}$, which give meaning to the jewelry and jade as the etiquette of the nature.

The chinese character Lǐ (禮) and Lí (醴) vividly indicate the food (jade) and wine given to the deity. The jade was the best media for the exchange of the power in the universe. So the origin of the worshiping of jade and eating jade was justified. Furthermore, in the expression of Fuyu (服玉), the meaning of “fu" indicates both eatable and wearable, which could be the origin of the etiquette of gentleman did not fail to wear their jade pendants.

\section{Conclusion}

The human's pursuit of exceed themself and the original body triggered the original etiquette. The holy and

\footnotetext{
${ }^{29}$ Yuan Ke, Collation and annotation to Shanhaijing (Classic of Mountains and Seas), Chengdu: Bashu Publishing House, 1996, pp. 48-49.

${ }^{30}$ Wang Xianqian, The Variorum of Xuncius, Peking: Zhonghua Book Company, 1988, p. 316.
} 
spiritual objects became the extension of body and the spiritual media. Different culture has different media, to China the jade was this media. This fact was showed in the Chinese character's code such as Ti (體) and Li (禮). This displays the deep relation between holy religion and mundane moral, the kind and pure pursuit. The relationship is shown as below: external body (physical appearance) —etiquette and jade (media) —internal virtue (sacred power or holy force). The paper thus reveals the power source of the birth of rites, which provide a new explanation of the origin of the "etiquette".

Jade was the essence of the nature contained in the stone and became the belief in the stone age. 8,000 years ago, the sacred feature of jade was gradually transformed into the daily life. It was cherished by people and became a daily fashion from a exclusive artifacts of the dignitary. But it never loses the sacred feature. The back side of the medal of Beijing Olympic Game in 2008 is inlayed with the jade Bi(disc) which design idea originated from chinese ancient jade Bi with dragon pattern (龙纹玉璧). The jade itself becomes the typical Chinese cultural symbol to mix with the goddess of victory in Greece. So the myth and belief of jade is suitable for the tradition of the Chinese culture ${ }^{31}$ and the fact of the moral and etiquette rules the society.

\section{References}

Deng, C. (ed.). (1998). Jade of East Asia. Hong Kong: The Chinese University of Hongkong Press.

Gu, J.G., \& Liu, Q. Y. (2005).Commentary and interpreter on the Book of History. Peking: Zhonghua Book Company.

Legge, J. (1976). The Lì Kī, Part IV in The Sacred Books of China. Motilal Banarsidass.

Mou, Y. K. (1993). Rice, silk and jade: Some questions on origin of Chiese civilization. The Journal of Archaeology, 6.

Pang, P. (1980). On five elenments of silk manuscripts. Jinan: Qi Lu Publishing House.

Ruan, Y. (2003). Commentaries on thirteen classics. Peking: Zhonghua Book Company.

Sun, Y. R. (1987). Commentary on rites of Zhou. Peking: Zhonghua Book Company.

Tang, Q. C. (2014). Li (禮, Etiquette). Ethnic Arts Quanterly, 3.

Wang, G. W. (2006). Guan Tang Ji lin (or Selected Works of Wang Guowei). Peking: Zhonghua Book Company.

Wang, X. Q. (1988). The variorum of Xuncius. Peking: Zhonghua Book Company.

Wu, Z. Y. (1982). Variorum of Yanzi's spring and autumn annals. Peking: Zhonghua Book Company.

Yang, R. B. (ed.). (1993). Qi theory and body concept in ancient Chinese thought. Taibei: Ju Liu Press.

Ye, S. X. (2010). Investigate on Myth Archetype of Chinese Saint. The Journal of WuhanUniversiry, 3.

Ye, S. X. (2010). On the myth root of confucianism and taoism view of belief of jade. Ethnic Arts Quanterly, 3.

Yuan, K. (1996). Collation and annotation of Shanhaijing. Chengdu: Bashu Publishing House.

Yuan, K. (1996). Collation and annotation to Shanhaijing (Classic of Mountains and Seas). Chengdu: Bashu Publishing House, pp. 48-49.

Zuo, Z. H. (2008). The Tomb of Zhao Jianzi: The final Luxuxy of the Father of Jinyang City. The Journal of Chinese Culture Heritage, 1.

${ }^{31}$ Ye Shuxian, On the myth root of confucianism and taoism view of belief of jade, Ethnic Arts Quanterly 2010.3. 